\title{
Cytological, Genetic, and Molecular Analysis to Characterize Compatible and Incompatible Interactions Between Medicago truncatula and Colletotrichum trifolii
}

\author{
Carine Torregrosa, ${ }^{1}$ Stéphanie Cluzet, ${ }^{1}$ Joëlle Fournier, ${ }^{1}$ Thierry Huguet, ${ }^{2}$ Pascal Gamas, ${ }^{2}$ \\ Jean-Marie Prospéri, ${ }^{3}$ Marie-Thérèse Esquerré-Tugayé, ${ }^{1}$ Bernard Dumas, ${ }^{1}$ and Christophe Jacquet ${ }^{1}$ \\ ${ }^{1}$ UMR 5546 CNRS-UPS, Pôle de Biotechnologie Végétale, 24 Chemin de Borde Rouge, BP17 Auzeville, 31326 Castanet- \\ Tolosan, France; ' 2 IPM, INRA-CNRS, 24 Chemin de Borde Rouge, BP27 Auzeville, 31326 Castanet-Tolosan, France; \\ ${ }^{3}$ Station de Génétique et d'Amélioration des Plantes, INRA, Domaine de Melgueil, 34130 Mauguio, France
}

Submitted 4 December 2003. Accepted 16 March 2004.

In this study, a new pathosystem was established using the model plant Medicago truncatula and Colletotrichum trifolii, the causal agent of anthracnose on Medicago sativa. Screening of a few $M$. truncatula lines identified Jemalong and F83005.5 as resistant and susceptible to Colletotrichum trifolii race 1, respectively. Symptom analysis and cytological studies indicated that resistance of Jemalong was associated with a hypersensitive response of the plant. The two selected lines were crossed, and inoculations with $C$. trifolii were performed on the resulting $F 1$ and F2 progenies. Examination of the disease phenotypes indicated that resistance was dominant and was probably due to a major resistance gene. Molecular components of the resistance were analyzed through macroarray experiments. Expression profiling of 126 expressed sequence tags corresponding to 92 genes, which were selected for their putative functions in plant defense or signal transduction, were compared in Jemalong and F83005.5 lines. A strong correlation was observed between the number of up-regulated genes and the resistance phenotype. Large differences appeared at $48 \mathrm{~h}$ postinoculation; more than $40 \%$ of the tested genes were up-regulated in the Jemalong line compared with only $10 \%$ in the susceptible line. Interestingly, some nodulin genes were also induced in the resistant line upon inoculation with $C$. trifolii.

Additional keywords: cell death, legume, phytoalexin, reactive oxygen species.

Besides constitutive physical or chemical barriers (Osbourn 1996), plants have developed an array of inducible, local, and systemic responses to defend themselves against pathogen attack (Dixon and Harrison 1994; Sticher et al. 1997). Following specific recognition of a pathogen, the hypersensitive response (HR) is a rapid and efficient plant resistance mechanism leading to cell death that is notably associated with the generation of reactive oxygen species (ROS) in and around the infected cell (Tenhaken et al. 1995). Other inducible and defense mechanisms involve cell-wall thickening (Esquerré-

Corresponding author: C. Jacquet; E-mail: : jacquet@ scsv.ups-tlse.fr

* The $\boldsymbol{e}$-Xtra logo stands for "electronic extra" and indicates the HTML abstract available on-line contains a supplemental table not included in the print edition.
Tugayé et al. 1999) as well as the production of antimicrobial compounds, such as phytoalexins (Hammerschmidt 1999), pathogenesis-related proteins (van Loon 1999), and enzyme inhibitors (Ryan 1990). Defense induction is regulated by a complex signal transduction network in which jasmonic acid, ethylene, and salicylic acid play a key role (Kunkel and Brooks 2002). Genomic and genetic tools such as microarrays and mutants, mainly developed on the model plant Arabidopsis thaliana, are being used to decipher this complex regulation (Glazebrook 2001; Glazebrook et al. 2003; Schenk et al. 2000; van Wees et al. 2003). However, despite the many advantages of $A$. thaliana, it has been shown recently that genetic data gained on this plant could not be fully applied to some other plants, notably to the legume family (Zhu et al. 2003).

Grain and forage legumes are the second most widely grown crops, after members of the family Poaceae (Graham and Vance 2003). Among the numerous pathogens that are responsible for severe economic losses on legumes, the Colletotrichum genus, causing anthracnose diseases, is particularly damaging. At least nine species have been identified on legumes in both temperate and tropical areas (Lenné 1992). Among them, $C$. lindemuthianum and $C$. trifolii, two closely related species (Sherriff et al. 1994), cause the highest losses, on bean and alfalfa, respectively.

Improvement of resistance to anthracnose in legumes is mainly focused on finding new sources of resistance and a better understanding of defense mechanisms. Several genes or quantitative trait loci associated with resistance against Colletotrichum spp. were found in alfalfa (Elgin and Ostazeski 1982), lentil (Tullu et al. 2003), and bean (Geffroy et al. 2000). The search for candidate genes in legume genomes has led to the identification of a large number of resistance gene analogues (Cordero and Skinner 2002). However, no resistance gene to any Colletotrichum sp. has yet been cloned. Major limitations to reaching this goal in legumes are the size and complexity of their genomes, the scarcity of genetic information, and difficulties encountered in transforming these plants. The use of diploid model legumes such as Medicago truncatula (Cook 1999) and Lotus japonicus (Handberg and Stougaard 1992), together with the large number of genomic tools available (VandenBosch and Stacey 2003), should overcome all these limitations, as recently demonstrated by the cloning of receptor kinase genes (Endre et al. 2002; Madsen et al. 2003; Stracke et al. 2002). In the field of legume-microbe interactions, these two model plants are extensively used to study root symbiosis (Stougaard 2001). In 
contrast, despite the production of $M$. truncatula cDNA libraries from elicited cells and pathogen-infected organs (Cook and Dénarié 2000), the genomic and genetic resources of this model plant have not been widely exploited to characterize $M$. truncatula-pathogen interactions. Some aspects of defense mechanisms in $M$. truncatula have been recently examined through global genomic approaches (Dixon et al. 2002; Suzuki et al. 2002). However, in order to study the resistance of $M$. truncatula by such approaches, it is necessary to define a suitable pathosystem that could allow the analysis of compatible and incompatible interactions.

This paper reports on the characterization and validation of such a pathosystem involving two Medicago truncatula lines and Colletotrichum trifolii. Responses of both lines to this fungus were characterized cytologically and by gene expression analysis performed through macroarray experiments using a "diagnostic defense and signaling" set of expressed sequence tags (EST). These studies showed that resistance was linked to localized HR lesions and to induction of a large number of defense genes. Contrasting expression patterns between the two lines were also found for some nodulin genes. Genetic analysis performed on the progeny derived from crossing the two lines indicated that resistance is likely to be governed by a major locus.

\section{RESULTS}

\section{Identification of resistant and susceptible lines.}

Four Medicago truncatula lines (DZA 45.5, DZA 315.16, F83005.5, and Jemalong 6), whose genetic backgrounds are well-characterized (Thoquet et al. 2002; T. Huguet, unpublished results), were challenged with $C$. trifolii race 1 . For each line, the response to $C$. trifolii infection was assessed on intact plants and on detached leaves. Following inoculation of either detached leaves or intact plants, two contrasting phenotypes were observed among the four lines at 9 and 14 days postinoculation (dpi), respectively. Severe anthracnose symptoms were displayed by F83005.5- (Fig. 1E) and DZA45.5inoculated (not shown) intact plants, most stems being typically collapsed. Dark acervuli developed on the stems and leaves (Fig. $1 \mathrm{~K}$ and L), and more than $80 \%$ of the inoculated plants died. A similar level of susceptibility was observed for these two lines (Fig. 1F) when detached leaves were inoculated. Scattered lesions were visible beneath the inoculum droplet from 3 dpi. Chlorotic tissues were observed around the inoculated area after 4 to $5 \mathrm{dpi}$. At the end of the experiment, a yellow halo surrounded a fully necrotic area in which darker pinpoint lesions could be found (Fig. $1 \mathrm{~K}$ and L). On some leaves, typical anthracnose dry lesions with brown borders were present (Fig. 1F). In contrast, neither anthracnose symptoms nor acervuli production were detected in Jemalong (Fig. 1B) and DZA 315.16 (not shown) inoculated plants. Most plants displayed small necrotic lesions on the aerial parts. This phenotype was confirmed on detached leaves. Upon inoculation, most leaves showed a few necrotic cells beneath the inoculation droplet at $3 \mathrm{dpi}$ but no typical anthracnose symptoms (Fig. 1C); other leaves remained entirely symptomless.

These results indicated that F83005.5 and DZA45.5 lines were susceptible to $C$. trifolii race 1 , whereas Jemalong and DZA 315.16 lines were resistant to this fungus. We focused on F83005.5 and Jemalong lines for further studies, because F2 seeds were already available from a cross between these lines. Since the two inoculation procedures, i.e., detached leaves and intact plants, yielded very similar results, the convenient and reproducible assay using detached leaves was retained to further analyze the cellular, molecular, and genetic components of M. truncatula resistance to $C$. trifolii.
Microscopic analysis of inoculated leaves.

Histological analyses were performed to monitor the kinetics of tissue colonization by the pathogen. Inoculated leaves were cleared and fungal structures were detected by aniline blue staining (Fig. $1 \mathrm{G}$ to $\mathrm{L}$ ). No significant differences were noted between resistant and susceptible lines during the prepenetration events (Fig. 1G and J). Spores germinated on the leaf surface and formed appressoria between 16 and $48 \mathrm{~h}$ after inoculation (hpi). Following penetration, fungal colonization proceeded rapidly in F83005.5 cells, and cell walls were disrupted beneath the whole inoculated area (not shown). From 5 to $6 \mathrm{dpi}$, dark acervuli with long setae were produced. These fructifications ruptured the epidermis of infected leaves and released $C$. trifolii conidia (Fig. $1 \mathrm{~K}$ and L). In contrast, fungal development was very limited in Jemalong inoculated leaves. Following mature appressorium formation, primary hyphae were produced but the mycelium was barely detectable. Groups of necrotic brown epidermal or mesophyll cells were observed from 4 to 5 dpi beneath or close to the appressoria (Fig. 1H and I). Acervuli were never seen in Jemalong leaves.

\section{Detection of $\mathrm{H}_{2} \mathrm{O}_{2}$ and phenolic compounds.}

Diaminobenzidine (DAB) was used to detect endogenous $\mathrm{H}_{2} \mathrm{O}_{2}$ production in inoculated leaves (Fig. 1M, N, P, and Q). Large differences were found between Jemalong and F83005.5, from 1 to 3 dpi. A reddish-brown staining due to DAB reaction products was observed beneath the inoculation drop in Jemalong leaves as early as $24 \mathrm{hpi}$, indicating the accumulation of $\mathrm{H}_{2} \mathrm{O}_{2}$ (Fig. 1M). Magnification of a stained area showed that granulated epidermal and mesophyll cells with dark-brown deposits were located under or close to appressoria (Fig. 1N). At 48 and $72 \mathrm{hpi}$, the size of the brown area increased, suggesting that amplification and propagation of the oxidative burst occurred in the inoculated area. In contrast, very few cells, if any, were stained with DAB when F83005.5 leaves were examined at any timepoint during the first $3 \mathrm{dpi}$, and granulation was never observed in the cytoplasm (Fig. 1P and Q).

The accumulation of autofluorescent phenolic compounds in inoculated leaves was detected by epifluorescence microscopy (Fig. 10 and R). In Jemalong leaves, accumulation of autofluorescent compounds started around 2 dpi beneath the inoculation droplet. Autofluorescence reached a maximum intensity between 3 and 4 dpi (Fig. 1O) and progressively decreased thereafter (not shown). In F83005.5 leaves, a delay in the detection of autofluorescence was recorded. Although small lesions linked to fungal development were observed at 3 dpi, only a few cells within the inoculated area were fluorescent (Fig. 1R). The fluorescence intensity increased slightly at 7 dpi but never reached the level detected in Jemalong leaves.

Symptom observations together with cytological observations suggested that the resistance to $C$. trifolii race 1 took the form of a $\mathrm{HR}$ in which penetrated host cells and some surrounding uninfected cells rapidly died, $\mathrm{H}_{2} \mathrm{O}_{2}$ and phenolic compounds were produced, and fungal colonization was restricted.

\section{Segregation analysis of the resistance to $C$. trifolii.}

The resistant Jemalong and the susceptible F83005.5 parental lines were crossed manually to obtain F1 plants (Thoquet et al. 2002). Self-fertilization of one of these plants yielded the F2 population. The response of these plants to $C$. trifolii race 1 was assessed, using the detached leaf assay. A total of 20 leaves from the F1 plant were inoculated. These leaves generally showed small necrotic areas after eight days, indicating a fully resistant phenotype. Although the parental lines displayed contrasting responses (susceptible or resistant), observation of 

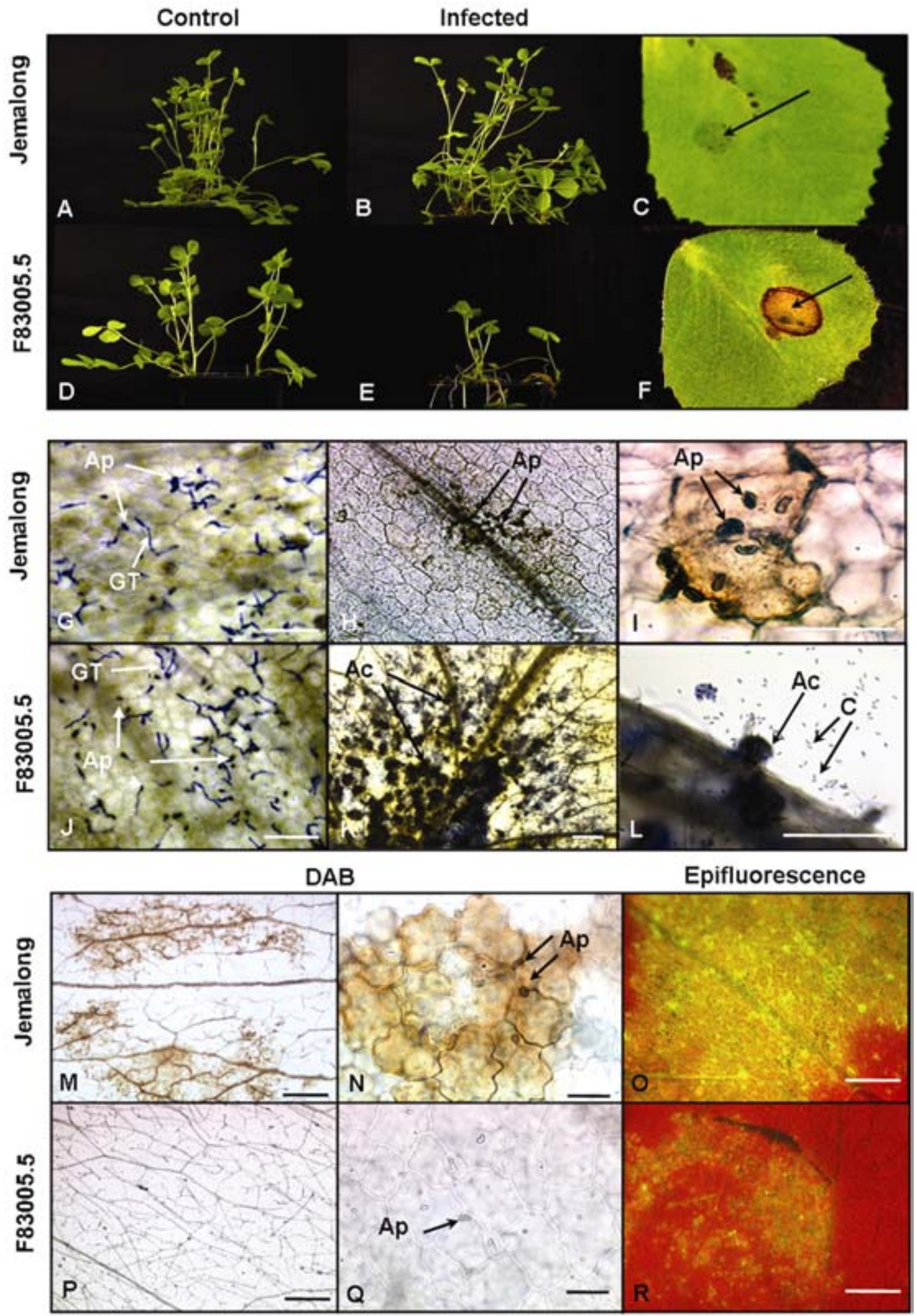

Fig. 1. Symptomology and microscopic analysis of Medicago truncatula Jemalong and F83005.5 plants and detached leaves inoculated with Colletotrichum trifolii race 1. A to F, Phenotypes observed on whole plants (B and E) and detached leaves (C and F), 14 and 9 days postinoculation (dpi), respectively. Noninoculated whole plants (A and D) are shown as controls. Upon inoculation with C. trifolii race 1, Jemalong plants did not show any disease symptoms (B), while most F83005.5 plants collapsed (E). Accordingly, typical anthracnose symptoms were observed on inoculated F83005.5 leaves (F) but not on Jemalong leaves (C). Note that the purple mark on the Jemalong leaf is a natural feature of this line. Inoculation point is indicated by an arrow. $\mathbf{G}$ to $\mathbf{L}$, Microscopic analysis of inoculated leaves. Mycelium was stained with aniline blue and observations were performed 1 dpi (G and J), 5 dpi (H,K,I), and 6 dpi (L). Prepenetration fungal development was similar in Jemalong and F83005.5 leaves ( $\mathrm{G}$ and J). Dark acervuli were produced 5 to 6 dpi on F83005.5 leaves (K and L). At that time, necrotic cells were observed beneath the appressoria ( $\mathrm{H}$ and I). Bars $=25 \mu \mathrm{m}$. Ac $=$ acervulus; $\mathrm{Ap}=$ appressorium; $\mathrm{C}=$ conidium; and $\mathrm{GT}=\mathrm{germ}$-tube. $\mathbf{M}$ to $\mathbf{R}$, Detection of $\mathrm{H}_{2} \mathrm{O}_{2}$ and phenolic compounds in inoculated leaves of the two lines. Leaves were stained with diaminobenzidine at 1 dpi (M, N, $\mathrm{P}$, and $\mathrm{Q}$ ). Autofluorescence of phenolics was observed with excitation by blue light at 3 dpi $(\mathrm{O}$ and $\mathrm{R})$. Brown staining, indicating the accumulation of $\mathrm{H}_{2} \mathrm{O}_{2}$ and intense fluorescence due to the accumulation of phenolic compounds were observed in Jemalong only ( $\mathrm{M}$ to $\mathrm{O})$, remaining very low in F83005.5 leaves $(\mathrm{P}$ to $\mathrm{R})$. Ap $=$ appressorium, $\mathrm{Ac}=$ acervulus, and $\mathrm{C}=$ conidium. Bars correspond to $200 \mu \mathrm{m}(\mathrm{M}$ and $\mathrm{P}), 15 \mu \mathrm{m}(\mathrm{N}$ and $\mathrm{Q})$, and $50 \mu \mathrm{m}(\mathrm{O}$ and $\mathrm{R})$. 
the inoculated F2 leaves revealed a range of intermediate phenotypes (Fig. 2). A disease index was therefore established to describe the phenotypes (Fig. 2). According to this index, each plant was assigned to one of five classes, ranging from 1 (fully resistant) to 5 (fully susceptible). Most Jemalong inoculated plants were recorded in class 2 , the remainder being symptomless (class 1), while more than $80 \%$ of the challenged F83005.5 leaves displayed severe anthracnose symptoms (class 5), the remaining inoculated plants belonged to classes 3 and 4 . Plants belonging to classes 1 and 2 were therefore considered as resistant, whereas plants within classes 3 to 5 were considered as susceptible. Out of 254 tested F2 plants, 209 (82\%) were resistant whereas $45(18 \%)$ were susceptible to $C$. trifolii (Table 1). Most of the susceptible F2 plants (58\%) were recorded in the intermediate class 3 , while the percentage of plants belonging to this class was only $3.3 \%$ in the susceptible parental line. The $\chi^{2}$ value (7.19) was calculated with the assumption of a 3:1 ratio, but the hypothesis of one dominant resistance gene with a normal Mendelian segregation was rejected at the $1 \%$ level $(p=0.007)$.

\section{Construction and analysis of a "defense} and signaling-related" set of $M$. truncatula EST.

In plant-pathogen interactions, resistance, especially genefor-gene-specific resistance, is often associated with an early expression of defense-related genes. In order to further characterize the $M$. truncatula-C. trifolii interaction, a comparison of defense gene expression patterns in the resistant and susceptible lines was undertaken. To this end, a subset of defense and signaling-related cDNAs was extracted from the previously described MtB EST libraries (Journet et al. 2002) on the basis of sequence homology to known defense genes. A total of 126 M. truncatula cDNAs was polymerase chain reaction (PCR)amplified and printed. These cDNAs represent 92 putative genes (tentative consensus or TC), as defined by The Institute of Genomic Research, (MtGI release 7.0 EST) or MtC clus- ters, as defined by the Medicago EST Navigation System (MENS) database. According to their putative function, the targeted genes were classified into five main categories (Table 2): i) genes related to the phenylpropanoid pathway, mainly involved in the biosynthesis of medicarpin, the major phytoalexin of $M$. sativa plants; ii) genes encoding cell wall proteins that mainly belong to the hydroxyproline-rich glycoprotein (HRGP) superfamily, including extensins, proline-rich proteins, and arabinogalactan proteins; iii) general defense genes, mainly pathogenesis-related (PR) proteins; iv) genes involved in lipid-related signaling and the oxylipin pathway; v) nodulin genes, which where selected for their homology to defense-related genes (Gamas et al. 1996, 1998). Quality parameters and controls used to present and obtain macroarray results are described below.

\section{Expression profiling through macroarray analysis.}

Gene expression patterns were compared at four timepoints following inoculation $(16,24,48$, and $72 \mathrm{hpi})$ in the susceptible and resistant lines. This timing corresponded to the beginning of fungal penetration in plant tissue (most of the $C$. trifolii appressoria being formed between 12 and $24 \mathrm{hpi}$ ) and the onset of cell necrosis ( 3 to $4 \mathrm{dpi}$ ). The overall changes in gene expression occurring in resistant and susceptible plants are summarized in Figure 3. At 16 and $24 \mathrm{hpi}$, the proportion of up-regulated genes was slightly higher in Jemalong, the resistant line, than in F83005.5, the susceptible line. This proportion sharply increased at $48 \mathrm{hpi}$ and remained high at $72 \mathrm{hpi}$ in Jemalong. In contrast, it decreased after 48 hpi in the susceptible line, coincident with a noticeable increase in the proportion of repressed genes.

An overview of the expression patterns for all the selected genes in the Jemalong and F83005.5 lines (Fig. 4) was generated with Cluster and Treeview software packages (Stanford University). This hierarchical clustering placed the genes into four categories according to their expression patterns: group I
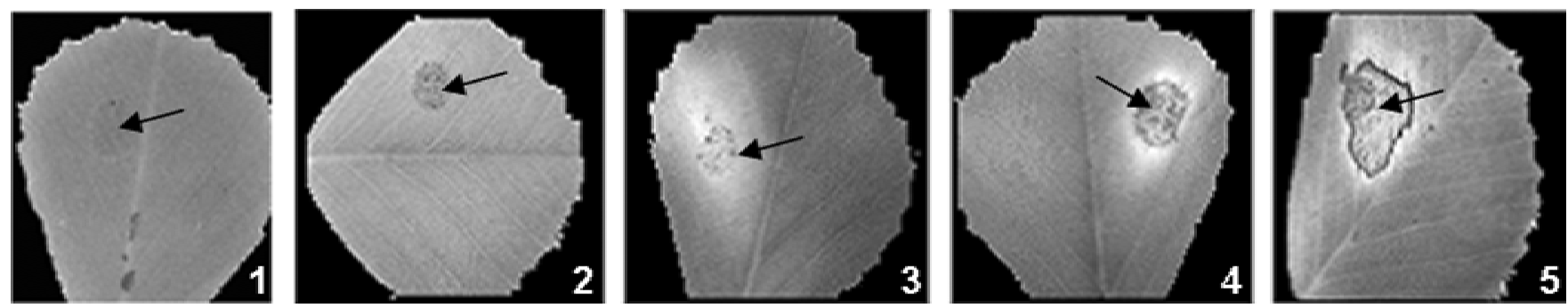

Fig. 2. Disease index established using detached leaflets of Medicago truncatula inoculated with Colletotrichum trifolii race 1 at 9 days postinoculation. One drop of conidia was applied on each leaflet, and symptoms were scored into five classes as follows: $1=$ symptomless, $2=$ scattered necrotic cells, $3=$ chlorotic area, most of leaf green, small lesions, $4=$ severely chlorotic leaf or large necrotic lesions, $5=$ large necrotic area with a dark brown border or severe chlorosis of the leaf, or both. Arrows indicate the points of inoculation.

Table 1. Segregation of resistance to Colletotrichum trifolii race 1 in Medicago truncatula parental lines and the F1 and F2 generations

\begin{tabular}{l} 
Total \\
\cline { 3 - 5 }
\end{tabular}


contains genes that are induced early but transiently (maximum level of expression at 16 or $24 \mathrm{hpi}$ ), group II contains genes whose induction is early and sustained, group III contains "late" induced genes (at 48 or $72 \mathrm{hpi}$, or both), and group IV contains repressed genes and genes with unchanged expression. In Jemalong, all four groups were represented, and more than two thirds of the analyzed genes were assigned to groups II and III. In contrast, group II was absent in F83005.5, the most frequent pattern being group IV (almost $50 \%$ of the genes) followed by group I. In this latter group, several early induced genes were significantly repressed at later timepoints in the susceptible line. These global comparisons between Jemalong and F83005.5 gene patterns highlighted significant quantitative differences. The number of induced genes as well as the durability of their induction were higher in the resistant line than in the susceptible one, as expected for defense-related genes.

To get more insight into the resistance mechanisms involved, the expression ratios of 72 genes that were found to be significantly up- or down-regulated (i.e., above 2 or below 0.5 respectively) for at least one timepoint in Jemalong or F83005.5, or both, were compared in the two lines (Table 3). A total of 46 genes were up-regulated in the resistant line only, while 11 genes were up-regulated in both lines and 10 genes were upregulated in the susceptible line only, confirming a large difference between the Jemalong response and the F83005.5 response. This difference was apparent for all categories of gene function except for the cell wall proteins, notably the extensin family, which were up-regulated in both lines. However, different cell wall protein genes were activated in Jemalong (TC87201) and in F83005.5 (TC76311, TC77527, and TC76555). In addition, some extensin genes were induced at late timepoints in the resistant line, whereas these genes were not activated or even repressed at these timepoints in the susceptible line.

Apart from a few isolated genes, all other gene classes were induced in the resistant line only. Most genes encoding PR proteins as well as enzymes of phytoalexin biosynthesis were mainly expressed at $48 \mathrm{hpi}$. However, two PR10 genes were noticeably induced throughout the $3 \mathrm{dpi}$. Two types of kinetics were observed for genes involved in pathways leading to the generation of signaling molecules (i.e., oxylipin pathway and oxidative burst): either an early induction (16 hpi) followed by a rapid decrease or delayed induction at 48 and $72 \mathrm{hpi}$. Among 12 genes encoding enzymes of the oxylipin pathway, 10 genes, i.e., one dioxygenase, one desaturase, six LOX, one hydroperoxide lyase, and one allene oxide cyclase, were significantly induced, thereby suggesting that lipid-derived signals might be involved in resistance in Medicago spp.

The representatives of five nodulin genes having some homology with defense protein were also tested on our arrays: MtN1 (a small Cys-rich gamma thionin-related gene), MtN5 (a nonspecific lipid transfer protein gene), MtN9 (encoding a

Table 2. Distribution of the analyzed expressed sequence tags (EST) and tentative consensus (TC) sequences of Medicago truncatula into gene categories

\begin{tabular}{lcc}
\hline Gene categories & EST & TC \\
\hline 1. Phytoalexin pathway & 28 & 17 \\
2. Cell wall proteins & 24 & 19 \\
3. Defense & 28 & 28 \\
4. Lipid-related signaling & 37 & 19 \\
5. Nodulins & 5 & 5 \\
6. Other genes & 4 & 4 \\
Total $^{\mathrm{a}}$ & 126 & 92 \\
\hline
\end{tabular}

${ }^{\mathrm{a}}$ Other genes correspond to three elongation factors and one trehalase. metalloendoproteinase-like protein), MtN13 (belonging to the PR10 family), and MtN16 (encoding a small Cys-rich leginsulin-related protein). All of them were found to be up-regulated in Jemalong leaves at least once during the analyzed timepoints. MtN13 was constantly induced between 24 and 72 hpi and, thus, displayed a similar expression pattern as the two PR10 genes analyzed. In the F83005.5 line, nodulin gene expression levels were unchanged during this plant-fungal interaction.

Changes in gene expression detected in macroarray experiments were validated by Northern blot analysis performed on eight $M$. truncatula genes. These genes (TC 86519, TC 85171, TC 86671, TC 76513, Y 10455, TC 85150, Y 15371, and TC $78197)$ belong to the five functional categories and were selected among the three groups of induced genes defined through macroarray results in the inoculated Jemalong line (Fig. 5). Comparison of the hybridization signals observed at each timepoint with the signal detected in the noninoculated control leaves gave results consistent with the ratios obtained through macroarray experiments (Table 3), whichever gene was examined.

\section{DISCUSSION}

The main purpose of this study was to set up a new pathosystem on the model legume M. truncatula (Barker et al. 1990; Cook 1999) that could be used to analyze the molecular and genetic components of legume resistance to fungal pathogens.
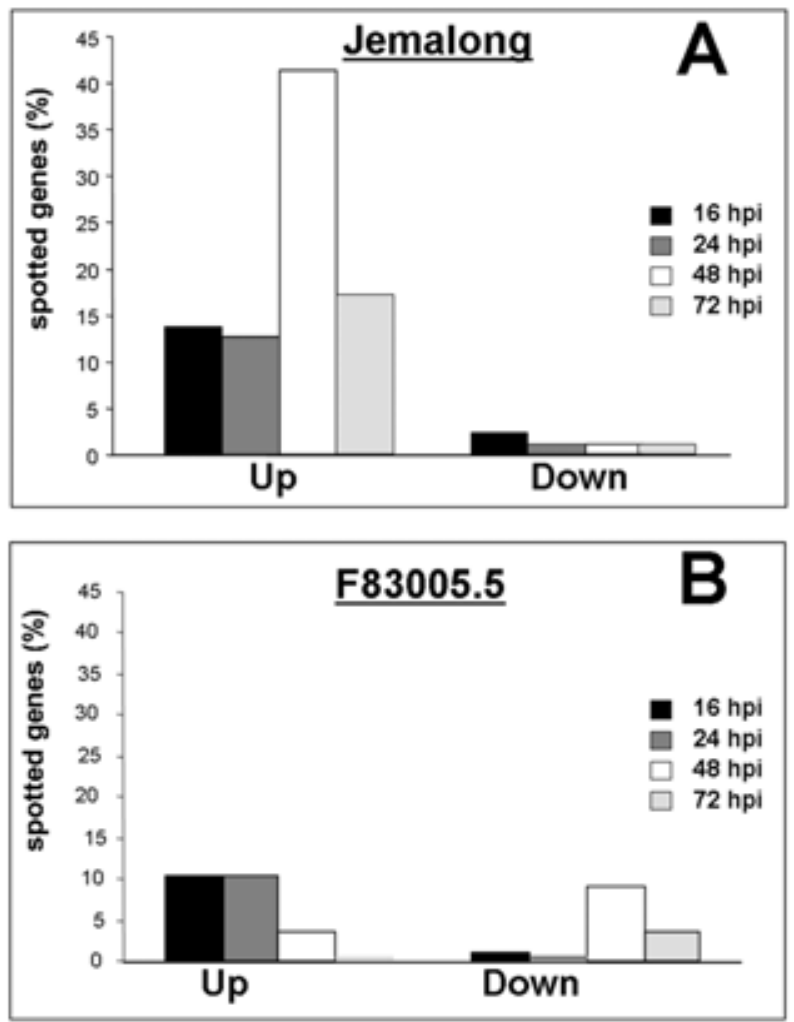

Fig. 3. Up- and down-regulated genes in Jemalong and F83005.5 plants at $16,24,48$, and $72 \mathrm{~h}$ after inoculation by Colletotrichum trifolii. Expression levels of 92 defense-related genes were assessed in macroarray experiments. At each timepoint, ratios between normalized signal values obtained from inoculated and noninoculated leaves were calculated. Gene induction and repression were considered as significant when ratios were above 2 and below 0.5 , respectively. Percentages were calculated according to the number of induced and repressed genes found for each timepoint of infection compared with the total number of tentative consensus sequences spotted on our array. 


\section{Jemalong}

$\begin{array}{llll}16 & 24 & 48 & 72\end{array}$

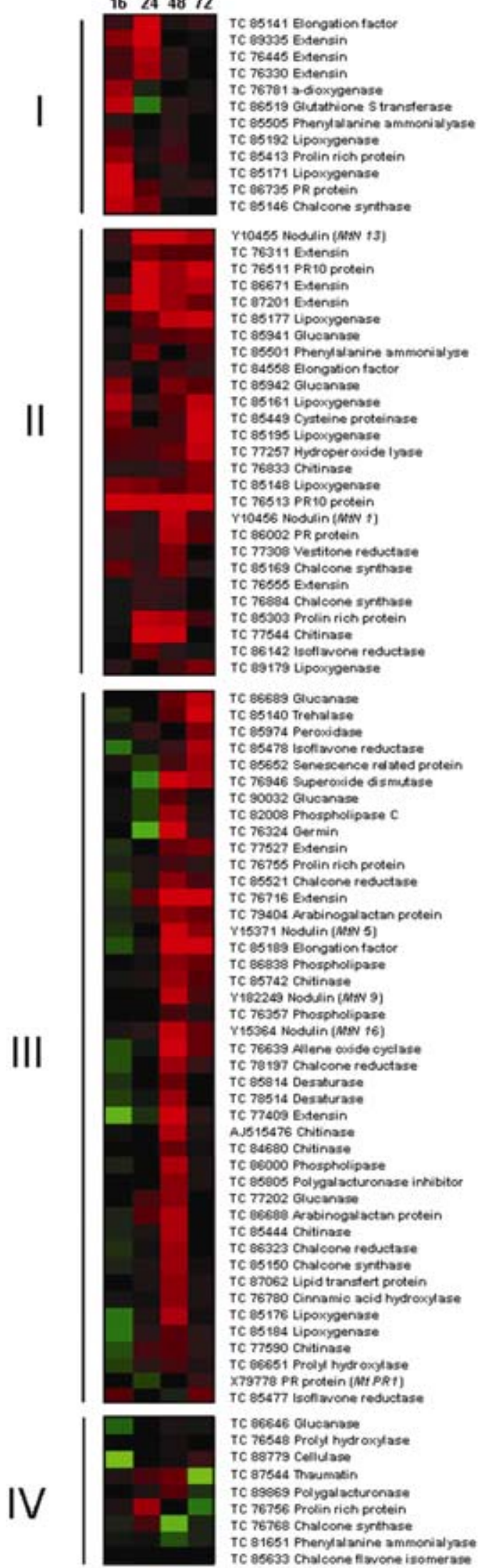

F83005.5

$\begin{array}{llll}16 & 24 & 48 & 72\end{array}$
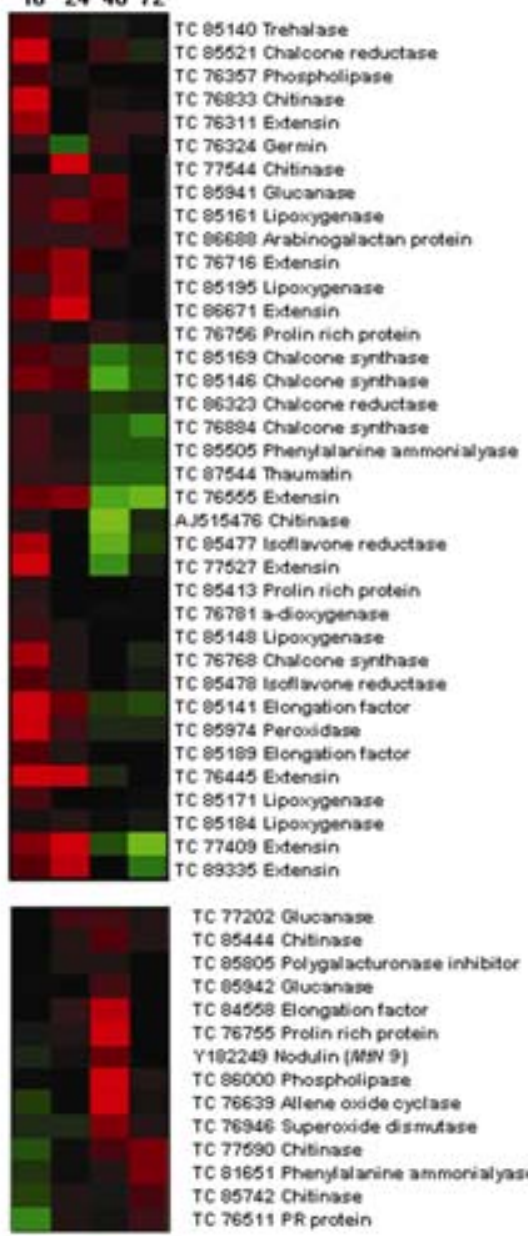

TC 77202 Gluoanase

TC 25444 Chitinase

TC 95805 Polygalacturonase inhibitor

TC 05942 Glucanase

TC 84568 Elongation factes

TC 76755 Prolin rich protein

$Y 102249$ Notulin (mever)

TC Os000 Phosphosip 9 )

TC 76639 Alene oxde oyelase

TC 76639 Alene oside oychase
TC 76946 superoxide dismatase

TC 77690 Chetnase

TC 81651 Phenylalarine ammorialyase

TC 85742 Chitinase

TC 76511 PR protein

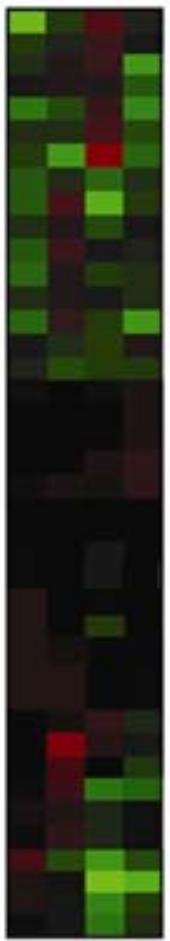

TC 05178 Lipoxypenase

TC 82003 Phospholipase

TC 35449 Cysteine proteinase

TC egecg Polvolucturonase

TC s56.33 Chyocone flavone isomerase

TC 78514 Dessturase

TC 78197 Chylcone reductase

TC 06519 Gitathione 5 tranaterase

TC 86846 Gluoanase

TC $\$ 8735$ PR protein

Y15364 Nodulin (WW 16)

TC 8 a 779 Cellulase

TC 86838 Phospholipase

TC B7201 Extensin

TC 85652 Senescence rd ated protein

TC 76548 Prolyl hydroxylase

TC 37062 Uipid transfert protein

TC \$5192 Liporopenase

TC 86689 Gluosnase

TC 77257 Hydroper oxdide lyase

TC 06002 PR protein

TC 76513 PRt 10 protein

Y15371 Noddin (WWN S)

TC 79404 Arabinogalactan protein

TC 85303 Prolin rich protein

TC 77308 Vestitone reductase

Y10456 Nodulin (Atw t)

TC 85501 Phendial anine ammorialyase

TC 26851 Prolyl hydroxylase

X79778 PR protein (MaPR1)

TC 24680 Chitinase

TC 76700 Cinnamie acid hydroxylase

TC 85142 isoliawone reductase

Y Y0655 Nodd in (MrN 13)

TC 05177 Lipospoenate

TC 89179 Lipoxypenas.

TC 76330 Extensin

TC 85814 Destuturase

TC 90032 Glucanase 
To achieve this goal, $C$. trifolii was used to challenge four $M$. truncatula accessions belonging to the French core collection (Prospéri 2000). Among the tested lines, Jemalong and DZA 315.16 were resistant to $C$. trifolii race 1, whereas F83005.5 and DZA 45.5 were susceptible. The high rate of resistance to $C$. trifolii observed in this small subset of accessions confirmed that $M$. truncatula is a good candidate to find new sources of resistance to this fungus, as previously suggested in studies on American accessions (Elgin and Ostazeski 1982; O'Neill and Bauchan 2000). The resistant phenotype was generally characterized by the presence of scattered necrotic cells or, occasionally, by the absence of macroscopic symptoms, while susceptible lines showed typical anthracnose dry lesions containing fungal fructifications. Jemalong and F83005.5 were selected as models of resistance and susceptibility, respectively, to $C$. trifolii, to further study the determinants of anthracnose resistance in $M$. truncatula. There was no significant difference in fungal development from spore germination to appressorium formation between these two lines, and differential host responses only became apparent after penetration. Typical anthracnose symptoms and the presence of acervuli were observed at 4 to 5 dpi in the susceptible line, indicating that the infection cycle had been completed. In the resistant line, fungal development was very limited, and necrotic cells were detected beneath appressoria at 3 to 4 dpi. Similar responses to $C$. trifolii have been reported in susceptible and resistant lines of $M$. sativa (Mould et al. 1991a and b). The presence of necrotic cells that prevent pathogen invasion in the resistant line is a typical feature of the HR process that occurs during incompatible interactions in many pathosystems and in other interactions of legumes with Colletotrichum spp. (Esquerré-Tugayé et al. 1992).

$\mathrm{H}_{2} \mathrm{O}_{2}$ has been reported to play an important role in the expression of hypersensitive disease resistance (Tenhaken et al. 1995). An early and massive production of $\mathrm{H}_{2} \mathrm{O}_{2}$ was induced in Jemalong leaves upon penetration of the pathogen, as shown by the intense staining of plant cells located beneath appressoria during the first $24 \mathrm{hpi}$. In comparison, DAB staining was barely detectable in F83005.5 inoculated leaves, indicating that the production of ROS could be a component of the incompatible interaction between $C$. trifolii and M. truncatula. This hypothesis is supported by the observation that the expression of germin and glutathione $S$ transferase genes, known to be associated with the production of ROS in plants (Wojtaszek 1997), increased in Jemalong only.

Examination of inoculated tissues by epifluorescence microscopy showed that autofluorescent phenolic compounds accumulated earlier and to a higher level in Jemalong. Such compounds are believed to play an active role in plant defense (Dixon et al. 1996, 2002). One of them, the phytoalexin medicarpin, is synthesized through the mobilization of several enzymes of the phenylpropanoid pathway. Several genes of this pathway, such as chalcone synthase (TC 85150) and chalcone reductase (TC 78197, TC 86323, and TC 85521), were induced at 48 hpi in Jemalong, consistent with the maximum level of autofluorescence observed at $72 \mathrm{hpi}$.

Results obtained following inoculation of F1 and F2 plants suggest that the observed differences in response to $C$. trifolii inoculation are likely to have a genetic basis. Indeed, segrega- tion analysis indicated that the resistance to $C$. trifolii was dominant, since the $\mathrm{F} 1$ progeny displayed the Jemalong resistant phenotype and the majority of F2 plants were resistant. This was consistent with the previous finding that, in the closely related $M$. sativa species, resistance against $C$. trifolii is also a dominant trait (Elgin and Ostazeski 1985). The result of the $\chi^{2}$ test applied to the F2 population was not consistent with the hypothesis of the Mendelian segregation of one gene. However, Thoquet and associates (2002) showed that more than $25 \%$ of the analyzed markers in a $M$. truncatula F2 population did not have the expected Mendelian ratios. Similar discrepancies were also observed in the segregation ratios of some symbiosis-related loci in L. japonicus (Kawaguchi et al. 2001). Only the detailed genetic mapping of this resistance trait will show whether resistance to $C$. trifolii is controlled in Jemalong either by only one gene showing a distorted segregation or by more than one gene. Resistance to C. truncatum in lentil was shown to be under the control of one major gene associated with several epistatic genes (Tullu et al. 2003). This might explain the presence of the intermediate susceptibility class (class 3 ) in the F2 progeny. The construction of a set of F6 recombinant inbred lines from the Jemalong $\times$ F83005.5 cross is underway and should allow these different hypotheses to be tested.

Besides genetic analysis, the defense responses associated with resistance of $M$. truncatula to $C$. trifolii were investigated. Macroarray analyses of a subset of signaling and defense genes revealed large differences between the two lines. Of the 68 genes reported in Table 3, a large proportion were induced in Jemalong and only a small proportion in the F83005.5 line, which also showed the highest number of repressed genes. This result fits well with the widely accepted concept that defense responses are delayed and less intense in susceptible plants than in resistant ones. More unexpectedly, we observed that, in some gene families, genes induced in susceptible plants were not the same as those induced in resistant plants, suggesting that defense responses in compatible interactions might not be just an attenuated version of the resistance responses.

Signaling is presumed to be a key component in plant resistance. Our macroarray included a set of genes involved in the production of lipid-derived signaling molecules such as jasmonic acid. More than 15 LOX genes can be predicted from the available $M$. truncatula EST sequences. Among the 10 LOX genes represented on the array, seven exhibited a modified transcript level, six of them being induced in the resistant line and only two in the susceptible line, suggesting the involvement of the oxylipin pathway in the resistance of Jemalong to $C$. trifolii. According to their expression patterns, LOX genes in Jemalong can be separated into early and late induced genes. This kind of biphasic regulation could be part of an "amplification loop" in which lipid-derived signals generated through the expression of the first set of genes might, in turn, induce the second set of genes as well as general defense genes. Such a mechanism has been proposed for jasmonic acid, the production of which is thought to induce genes of its own biosynthetic pathway (Turner et al. 2002) as well as defense genes, thus amplifying the signaling cascade. More detailed studies are now required to assess the participation of

Fig. 4. Hierarchical clustering of the 92 genes in Jemalong and F83005.5 lines at 16, 24, 48, and 72 hours postinoculation by Colletotrichum trifolii. Ratios calculated for each gene in the two lines were converted using Cluster and Treeview software (Stanford University) after normalization. Induced (ratio $>2$ ) and repressed (ratio <0.5) genes are shown in red and green, respectively, according to the scale at the bottom of the figure. Group I: genes transiently induced early during infection (16 and 24 hpi); Group II: genes induced throughout the analysis period; Group III: genes induced later (48 and 72 hpi); and Group IV: repressed or unchanged genes. 
Table 3. Expression ratios of genes induced or repressed after inoculation with Colletorichum trifolii ${ }^{\mathrm{a}}$

\begin{tabular}{|c|c|c|c|c|c|c|c|c|c|c|c|}
\hline \multirow[b]{2}{*}{ PUTATIVE FUNCTION } & \multirow[b]{2}{*}{ Genbank Accessions ${ }^{b}$} & \multirow[b]{2}{*}{$\mathrm{TIGR}^{c}$} & & Jen & along $(\mathrm{r}$ & esistant) & & F83 & $005.5(\mathrm{~s}$ & isceptibl & \\
\hline & & & MENS $^{d}$ & 16 hpi & $24 \mathrm{hpi}$ & 48 hpi & 72 hpi & $16 \mathrm{hpi}$ & 24 hpi & 48 hpi & 72 hpi \\
\hline Phytoalexin pathway & & & & & & & & & & & \\
\hline Chalcone reductase & AL.384992 & TC78197 & . & 0.63 & 1.11 & 2.30 & 1.44 & 0.79 & 0.51 & 1.95 & 0.64 \\
\hline Chalcone reductase & AL.384996 & TC86323 & - & 0.70 & 1.28 & 2.15 & 1.60 & 1.00 & 1.26 & 1.42 & 0.74 \\
\hline Chalcone reductase & AL.386345,AL.381630 & TC85521 & MrCo0294_GC & 0.74 & 1.13 & 2.23 & 1.43 & 3.35 & 1.01 & 1.46 & 0.83 \\
\hline Chalocone synthase & AL 368203 & TC85146 & $\mathrm{MiC} 10863.2 \mathrm{GC}$ & 2.51 & 1.88 & 1.12 & 1.05 & 1.85 & 1.60 & 0,45 & 0.66 \\
\hline Chalcone synthase & AL.384218 & TC85150 & MtD00121_GC & 0.79 & 1.29 & 2.17 & 1.18 & 1.07 & 1.87 & 1.36 & 0.79 \\
\hline Chalcone synthase & AL.366531 & TC76768 & MiC20397.5_GC & 0.78 & 1.55 & 0,42 & 0.83 & 2.15 & 1.33 & 1.17 & 0.74 \\
\hline Cinnanic acid hydroxylase & AL.385129,AL 386379 & TC76780 & Mic00747.1 GC & 0.84 & 1.14 & 2.12 & 1.24 & 0.93 & 1.56 & 1.12 & 0.71 \\
\hline Isoflavene reduxtase & AL. 383870 & TC85478 & $\mathrm{MiC} 00234.2 \mathrm{GC}$ & 0.56 & 0.87 & 1.44 & 2.46 & 1.61 & 1.31 & 1.07 & 0.82 \\
\hline Isoflavone reductase & AL.384237 & TC85477 & MiC00234.I_GC & 1.63 & 1.02 & 0.83 & 1.81 & 2.45 & 0.91 & 0.41 & 0.66 \\
\hline Cell wall proteins & & & & & & & & & & & \\
\hline ArabinoGalactanProtein & AL368602,AL386043 & TC79404 & MECl1007 GC & 0.77 & 1.30 & 2.05 & 1.83 & 1.06 & 1.05 & 0.95 & 1.13 \\
\hline ArabinoGalactanProtein & AL.381434 & TC86688 & MeC10757_GC & 0.80 & 1.62 & 2.36 & 1.06 & 1.60 & 1.56 & 1.62 & 1.23 \\
\hline Extensin & AL 382343 & TC89335 & MeC00455_GC & 2.16 & 3.06 & 1.09 & 1.16 & 1.82 & 2.63 & 0.85 & 0.53 \\
\hline Extensin & A.378354 & TC87201 & MEClO404_GC & 2.14 & 4.25 & 2.21 & 1.78 & 0.63 & 1.17 & 0.81 & 0.54 \\
\hline Extensin & AL 372402, AL 382536 & TC76330 & MiC 30178. IGC & 1.54 & 2.29 & 1.32 & 0.91 & 1.13 & 1.05 & 0.32 & 0.43 \\
\hline Extensin & AL370050 & TC76445 & $\mathrm{MrCl} 118 \mathrm{GC}$ & 1.54 & 2.32 & 1.36 & 1.03 & 3.14 & 2.50 & 0.72 & 0.87 \\
\hline Extensin & AL 386333 & TC86671 & $\mathrm{MeC} 93202$ GC & 1.31 & 4.45 & 2.18 & 2.44 & 1.87 & 2.77 & 1.28 & 1.15 \\
\hline Extensin & AL.389299 & TC77409 & $\mathrm{MtC} 00602$ GC & 0.41 & 0.75 & 2.92 & 1.39 & 2.08 & 3.92 & 0.62 & 0.36 \\
\hline Extensin & AL373614,AL 387264 & TC76716 & Mic00611.1_GC & 0.75 & 1.72 & 3.35 & 3.07 & 1.79 & 2.19 & 1.27 & 1.39 \\
\hline Extensin & AL.381854, AL.377108 & TC76311 & MiCO0023.1GC & 1.38 & 186 & 1.62 & 1.65 & 2.31 & 1.03 & 1.32 & 1.35 \\
\hline Extensin & AL370995 & TC77527 & MtC45475_GC & 0.75 & 0.92 & 1.83 & 1.94 & 3.75 & 1.11 & 0.48 & 0.72 \\
\hline Extensin & AL.385455 & TC76555 & MeC00039_GC & 0.85 & 1.41 & 1.42 & 0.96 & 1.80 & 2.02 & 0,45 & 0.58 \\
\hline Prolin Rich Protein & AL374012,AL 386974 & TC85413 & $\mathrm{M}: \mathrm{Cl} 10169 \mathrm{GC}$ & 2.05 & 1.27 & 1.56 & 1.06 & 1.45 & 0.97 & 0.84 & 0.81 \\
\hline Prolin Rich Protein & AL385945 & TC76756 & MtC00393_GC & 1.22 & 2.29 & 1.06 & 0.55 & 1.45 & 1.31 & 1.56 & 0.77 \\
\hline Prolin Rich Protein & AL.385158 & TC85303 & MeC00003_GC & 0.86 & 2.64 & 2.43 & 1.58 & 1.25 & 1.15 & 1.19 & 0.88 \\
\hline Prolin Rich Protein & AL 386722 & TC76755 & $\mathrm{M}: \mathrm{C} 00014 \mathrm{GC}$ & 0.84 & 1.29 & 1.50 & 1.35 & 0.84 & 1.32 & 2.68 & 1.04 \\
\hline Ceflulase & AL.382561 & TC88779 & MeC93374_GC & 0.26 & 1.14 & 1.19 & 1.50 & 0.64 & 1.07 & 0.83 & 0.85 \\
\hline Defence & & & & & & & & & & & \\
\hline Chitinase & A. 382692 & TC85742 & $\mathrm{M}=\mathrm{Cl} 10312$ GC & 0.90 & 1.20 & 2.21 & 1.67 & 0.72 & 1.16 & 0.94 & 1.47 \\
\hline Chitinase & AL 370332 & TC85444 & MECl0039 GC & 0.77 & 1.30 & 2.47 & 1.04 & 0.89 & 1.36 & 1.63 & 1.36 \\
\hline Chitinase & AL369958 & TC77544 & MtD22107_GC & 1.17 & 5.79 & 2.76 & 1.00 & 1.18 & 3.21 & 0.75 & 1.02 \\
\hline Chitinase & AL.380364 & TC76833 & MECl0306_GC & 1.38 & 1.32 & 1.45 & 1.91 & 3.60 & 1.03 & 1.15 & 1.08 \\
\hline Chitinase (MrChin) & ANS15476 & 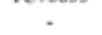 & - & 1.15 & 1.03 & 2.33 & 1.23 & 1.48 & 1.21 & 0.24 & 0.70 \\
\hline Cystein protease & AL379558 & TC85449 & MoC01675_GC & 1.85 & 1.08 & 1.58 & 2.68 & 0.88 & 1.06 & 1.24 & 0.53 \\
\hline Glucanase & AL.388209 & TC85942 & MeC00641_GC & 2.11 & 1.08 & 1.85 & 1.66 & 0.85 & 1.09 & 160 & 1.08 \\
\hline Glucanase & AL.374793 & TC77202 & MtC0064I GC & 0.95 & 1.56 & 2.02 & 0.98 & 0.84 & 1.60 & 1.55 & 1.30 \\
\hline Glucanase & AL.387547 & TC86689 & MeC00792_GC & 1.07 & 1.01 & 1.83 & 2.59 & 1.18 & 1.03 & 1.15 & 1.39 \\
\hline Glucanase & AL 378026 & TC86646 & MtC90920 GC & 0.57 & 0.95 & 1.39 & 0.80 & 0.68 & 1.32 & 0.46 & 0.84 \\
\hline Lipid Transfert Protein like & AL.386789 & TC87062 & $\mathrm{MrC0} 0336$ GC & 0.94 & 1.23 & 2.09 & 1.20 & 1.27 & 1.47 & 1.29 & 1.88 \\
\hline Peroxidase & AL 371852 & TC85974 & MeCl0717_GC & 0.85 & 1.42 & 1.05 & 1.88 & 2.54 & 1.51 & 0.74 & 0.75 \\
\hline Polygalacturoense inhibior & AL.381114 & TC85805 & $\mathrm{MeC1} 10369 \mathrm{GC}$ & 0.91 & 0.95 & 2.08 & 1.21 & 1.05 & 1.30 & 1.29 & 1.11 \\
\hline PRI protein & AL366041 & TC86735 & $\mathrm{MtC} 90030$ GC & 3.16 & 1.63 & 1.32 & 1.45 & 0.84 & 1.05 & 0.74 & 1.01 \\
\hline PR protein & AL386306 & TC86002 & MeC00352_GC & 1.46 & 1.39 & 2.47 & 1.64 & 1.06 & 1.11 & 1.32 & 1.42 \\
\hline PR10 protein & AL 382676 & TC76511 & M:C00219_GC & 1.04 & 3.37 & 2.23 & 2.68 & 0.58 & 1.18 & 1.07 & 1.36 \\
\hline PR10 protein & AL373773 & TC76513 & $\mathrm{M}+\mathrm{C} 00009$ GC & 3.26 & 2.76 & 2.77 & 3,40 & 1.24 & 1.31 & 0.79 & 1.43 \\
\hline Senescence Related Gene & AL379718 & TC85652 & MeC 30088 GC & 1.24 & 0.67 & 1.53 & 2.17 & 1.01 & 0.87 & 0.80 & 1.07 \\
\hline Thaumatin like protein & AL 368254 & TC87544 & MtCl0994_GC & 1.39 & 1.64 & 1.92 & 0.16 & 1.33 & 1.25 & 0.60 & 0.58 \\
\hline Germin & AL 366942 & TC76324 & $\mathrm{M}=\mathrm{C} 00172 \mathrm{GC}$ & 0.93 & 0.44 & 4.93 & 1.38 & 1.38 & 0.61 & 1.43 & 1.10 \\
\hline Glutathione S transferase & AL365865 & TC86519 & MtC20385_GC & 2.61 & 0.55 & 1.37 & 1.20 & 0.71 & 0.89 & 0.64 & 0.85 \\
\hline Superoxide dismutase & AL375556 & TC76946 & MeC00676_GC & 0.99 & 0.52 & 2.74 & 2.33 & 0.67 & 0.68 & 2.07 & 1.48 \\
\hline$\underline{\text { Lipid-related signalling }}$ & & & & & & & & & & & \\
\hline$\alpha$-dioxygenase & * & TC76781 & $\mathrm{MeCl} 10023 \mathrm{GC}$ & 2.17 & 0.81 & 1.09 & 0.85 & 1.53 & 0.87 & 0.80 & 0.84 \\
\hline Allene oxide cyclase & AL.366445,AL 378875 & TC76639 & MtCl0265_GC & 0.64 & 0.86 & 3.03 & 1.75 & 0.63 & 0.88 & 2.85 & 1.38 \\
\hline Hydroperovide lyase & \# & TC77257 & MeC40021_GC & 1.58 & 1.54 & 1.72 & 2.53 & 1.03 & 0.99 & 1.12 & 1.34 \\
\hline Desaturase & AL.377135,AL 381596 & TC78514 & MtC2025I GC & 0.69 & 0.86 & 2.26 & 1.04 & 0.89 & 0.90 & 1.33 & 0.78 \\
\hline Lipoxygenase & AL.380743 & TC85195 & $\mathrm{MeCl} 10070$ GC & 2.35 & 1.38 & 1.65 & 2.61 & 1.51 & 2.25 & 1.36 & 0.98 \\
\hline Lipoxygenase & AL380164,AL 378899 & TC85171 & $\mathrm{MtC} 40012$ GC & 3.61 & 1.16 & 1.34 & 1.15 & 1.68 & 1.08 & 0.91 & 0.79 \\
\hline Lipoxygenase & ** & TC85148 & MeC00630_GC & 2.07 & 1.92 & 1.72 & 1.86 & 1.55 & 1.31 & 1.13 & 0.89 \\
\hline Lipoxygenase & AL.380777 & TC85176 & MECI044I GC & 0.58 & 1.23 & 2.40 & 1.18 & 0.38 & 0.82 & 1.48 & 0.94 \\
\hline Lipoxygenase & AL.371201,AL 386894 & TC85177 & Mic00480.1 GC & 1.09 & 1.78 & 2.51 & 2,70 & 1.11 & 1.29 & 0.80 & 0.93 \\
\hline Lipoxygenase & \#\# & TC85161 & MiCl0146.1_GC & 1.63 & 1.51 & 1.50 & 2.74 & 1.37 & 1.41 & 0.79 & 0.78 \\
\hline Lipoxygenase & AL.373094 & TC85184 & $\mathrm{MeC} 40129 \mathrm{GC}$ & 0.55 & 1.31 & 1.71 & 1.34 & 1.62 & 2.09 & 1.82 & 1.35 \\
\hline Lipoxygenase & AL. 377640 & TC89179 & MeC90890_GC & 1.33 & 0.98 & 1.56 & 1.93 & 1.46 & 0.69 & 0.48 & 0.71 \\
\hline Phospholipase & AL.380498,AL.388846 & TC82008 & Mec20027_GC & 1.13 & 0.71 & 2.21 & 1.19 & 0.82 & 0.95 & 1.20 & 1.02 \\
\hline Phospholipase & AL370139 & TC86838 & 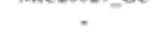 & 1.03 & 1.14 & 2.11 & 1.78 & 0.88 & 1.05 & 0.98 & 0.89 \\
\hline Phospholipase & AL.382517 & TC 86000 & MeC20393_GC & 0.82 & 0.91 & 2.35 & 1.29 & 0.83 & 0.99 & 2.91 & 1.41 \\
\hline Nodulins & & & & & & & & & & & \\
\hline MtNI & Y10456 & TC 86337 & MtC0006s_GC & 1.58 & 1.40 & 2.59 & 1.60 & 1.30 & 0.99 & 0.67 & 1.01 \\
\hline MiNi3 & Y10455 & TC78739 & $\mathrm{M}=\mathrm{Cl} 10690 \mathrm{GC}$ & 1.45 & 3.58 & 3.03 & 2.33 & 1.11 & 1.24 & 0.82 & 0.93 \\
\hline MtN16 & Y15364 & TC87718 & MrCO0186_GC & 1.20 & 1.33 & 2.59 & 1.72 & 0.69 & 1.24 & 1.03 & 096 \\
\hline MiNs & Y15371 & TC76902 & MiC00060.1_GC & 0.72 & 1.07 & 2.66 & 2.06 & 1.01 & 1.05 & 1.02 & 0.94 \\
\hline MiN9 & Y18249 & TC79334 & MeC40019_GC & 1.01 & 1.01 & 2.50 & 1.56 & 0.78 & 1.19 & 1.72 & 0.93 \\
\hline Others & & & & & & & & & & & \\
\hline Elongation factor & AL.373197 & TC85141 & . & 1.41 & 251 & 1.19 & 1.42 & 250 & 1.73 & 0.70 & 0.67 \\
\hline Elongation factor & AL. 369516 & TC85189 & MtC20189_GC & 0.66 & 1.22 & 3.43 & 3.35 & 1.68 & 1.39 & 0.99 & 0.88 \\
\hline Elongation factor & AL.373731 & TC84558 & MeC90590_GC & 1.42 & 1.17 & 1.51 & 1.47 & 0.96 & 1.42 & 2.37 & 1.17 \\
\hline Trehalase & AL381361 & TC85140 & MtD22319 GC & 0.74 & 1.10 & 1.61 & 3.87 & 1.63 & 0.93 & 0.87 & 1.08 \\
\hline
\end{tabular}

${ }^{a}$ Expression ratios correspoind to inoculated versus noninoculated normalized values obtained in two or three independent experiments. Only genes that showed ratios $>2$ (black boxes) or $<0.5$ (white boxes) for at least one timepoint were considered as significantly induced or repressed.

$\mathrm{b} *=\mathrm{AL372114}$, AL381446, AL381507, AL386249; \# = AL372355, AL383005, AL377171; ** = AL370268, AL372698, AL381315; \#\# = AL379191, AL380284, AL368374

${ }^{c}$ Tentative consensus (TC) number according to The Institute of Genome Research.

${ }^{\mathrm{d}}$ TC number according to Medicago EST Navigation System. 
LOX genes in the incompatible interaction between Jemalong and $C$. trifolii race 1 . This is particularly relevant in view of the association of the LOX pathway with plant resistance to various pathogens, as demonstrated in the interactions between Phaseolus vulgaris and Pseudomonas syringae pv. phaseolicola (Croft et al. 1993) and between Nicotiana tabacum and Phytophthora parasitica var. nicotianae (Mène-Saffrané et al. 2003; Rancé et al. 1998).

Expression patterns of genes belonging to the HRGP extensin family deserve a special comment. Several cDNAs encoding members of this gene family were included in our set of EST. About half of them were induced during the first 24 hpi in both lines. Although induction was still observed at 48 and 72 hpi for some extensin genes in Jemalong plants, the transcript level of these genes strongly decreased from $48 \mathrm{hpi}$ in the susceptible line. Such results fit with the previous finding that enzymes secreted by Colletotrichum spp. release plant cell wall oligosaccharides that then act as endogenous suppressors of HRGP gene expression (Boudart et al. 1995).

On the basis of their homology with defense-related genes in other species, five nodulin genes were also included in the spotted EST. They had been found previously to be expressed exclusively at specific stages of nodulation (Gamas et al. 1996, 1998; Szybiak-Strozycka et al. 1995). Our results showed that these genes were also induced in the resistant interaction between $C$. trifolii and $M$. truncatula. This was confirmed for three of the genes by Northern analysis, although expression was at a much lower level than in root symbiotic interactions with S. meliloti. One of them, MtN13, was induced throughout the 3 dpi. This gene, which displays similarity with MtPR10-1 at the protein level, had the same expression pattern as the two MtPRIO genes that were spotted on our array. Cross-hybridization between MtN13 and PR10 genes was unlikely, because the Northern blot analysis (Fig. 5) showed a different pattern for MtN13 and TC76513 (PR10). In view of these results, an intriguing question is why no MtN13 transcript induction was detected in leaves infiltrated by pathogenic bacteria inducing an HR-like response in M. truncatula (Gamas et al. 1998). A possible explanation is that the HR induced by bacteria or fungi are associated with the expression of distinct although overlapping sets of defense genes. This may be related to their differing mechanisms of infection. For example, enzymes secreted by Colletotrichum spp. are well known to release oligosaccharide elicitors from plant cell walls (Boudart et al. 1995), whereas cell wall degradation does not occur in a plant-bacteria incompatible interaction (Brown et al. 1995). Another hypothesis is that the necrosis induced by the bacteria in $M$. truncatula was due to a nonhost incompatible reaction and not to a race-cultivar specific incompatible interaction. Plant mechanisms involved in these two kinds of resistance are different, especially for bacteria experimentally introduced into plant tissues (Heath 2000). In any case, the fact that symbiotic and pathogenic interactions taking place in different organs share some up-regulated genes can have various explanations, as discussed in several recent articles (Mithöfer 2002; Parniske 2000). One possibility is that the infection process of symbiotic bacteria could trigger some limited defense responses, which may control the extent of $S$. meliloti infection or limit opportunistic invasion by nonsymbiotic microorganisms.

In this work, a hitherto undescribed pathosystem between $M$. truncatula and $C$. trifolii was characterized by means of complementary cytological, genetic, and molecular approaches. The clear compatible and incompatible interactions defined in this system could serve as a basis to study resistance in other legumes. In addition, the diagnostic defense and signaling set of EST used in this study, although representative of a limited number of genes, should be valuable for comparing the defense mechanisms involved in other $M$. truncatulamicrobe interactions.

\section{MATERIALS AND METHODS}

Plant materials and growth conditions.

Seeds of Medicago truncatula Gaertn accessions Jemalong 6, the Algerian DZA 315.16 and DZA 45.5, and the French F83005.5 were provided by the INRA Génétique et Amélioration des Plantes department, Mauguio, France. Seeds were first treated with pure sulphuric acid for $5 \mathrm{~min}$. After three washes in sterile water, they were allowed to germinate on $1 \%$ agar plates for three days at $15^{\circ} \mathrm{C}$ in the dark. Seedlings were transferred to soil and were cultivated in a growth chamber with a 16 -h light, $20^{\circ} \mathrm{C}$ and 8 -h dark, $15^{\circ} \mathrm{C}$ regime for three to six

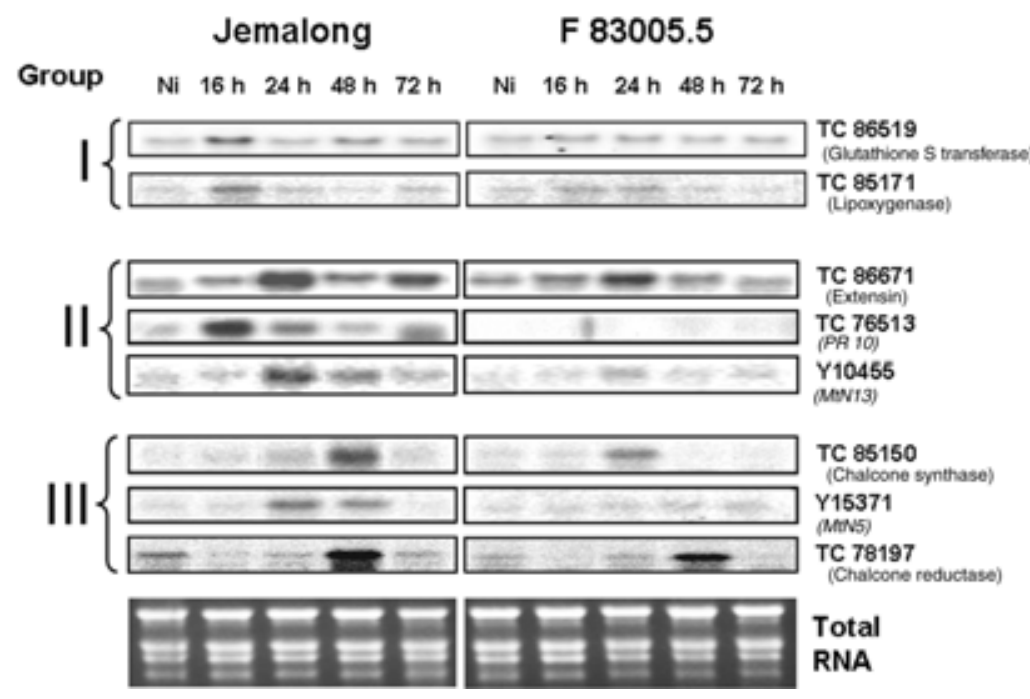

Fig. 5. Northern blot analysis of eight selected Medicago truncatula genes in the Jemalong and F83005.5 lines inoculated with Colletotrichum trifolii or noninoculated control plants (Ni). Total RNA from inoculated leaves was extracted at 16, 24, 48, and $72 \mathrm{~h}$ after inoculation by $C$. trifolii. Polymerase chain reaction amplified fragments obtained from plasmids containing expressed sequence tags belonging to the tentative consensus sequences indicated on the right of each autoradiograph were used as probes for hybridization. Loading of the same amount of total RNA (15 $\mu \mathrm{g})$ for each timepoint was controlled by ethidium bromide staining after blotting RNAs onto a nylon membrane. Group numbers were defined according to the expression patterns observed in the Jemalong line through macroarray results. 
weeks. A cross between Jemalong and F83005.5 was obtained by a manual crossing procedure (Thoquet et al. 2002). Jemalong plants were fertilized with pollen harvested from F83005.5 plants. Seeds were subsequently collected, and successful cross-fertilization was confirmed in a few F1 plants with molecular markers (T. Huguet, unpublished data). One of the hybrid F1 plants was grown further in a greenhouse, and F2 seeds were collected after self-fertilization of this plant.

\section{Inoculation procedures.}

Colletotrichum trifolii Bain and Essary race 1, as determined with Arc and Saranac alfalfa cultivars (Elgin and Ostazeski 1985), was supplied by M. B. Dickman, University of Nebraska, Lincoln, NB, U.S.A. Mycelium was routinely grown on ANM plates (malt extract $2 \%$, bactopeptone $0.1 \%$, glucose $2 \%$, agar $2 \%$ ) in the dark at $23^{\circ} \mathrm{C}$ in petri dishes. Conidia were produced after seven days at $23^{\circ} \mathrm{C}$ on Bannerot medium (Bannerot 1965). Spores were collected in sterile water, and the concentration was adjusted to $10^{6}$ cells per $\mathrm{ml}$ in $0.01 \%$ Tween 20 (Sigma, St. Louis). In the detached leaf assay, freshly harvested leaves were laid on wet paper (3MM, Whatman, Maidstone, England) in petri dishes, and 6- $\mu$ l droplets of the spore suspension were pipetted on the adaxial surface of each leaflet. Droplets of $0.01 \%$ Tween 20 solution were applied for control leaves. Petri dishes were transferred to a growth chamber programmed for a 16-h light, $22^{\circ} \mathrm{C}$ and 8 -h dark, $20^{\circ} \mathrm{C}$ regime. For segregation analysis in the $\mathrm{F} 2$ population, two leaves (six leaflets) from each plant were inoculated. The experiment was repeated at least once, 1 week later, with the same plants. Symptoms were recorded 9 dpi. For intact plant inoculation, the spore suspension was sprayed onto 4-week-old plants, which were then grown for a further 14 days in the same light and temperature conditions and $90 \%$ relative humidity. Symptoms were observed at $14 \mathrm{dpi}$.

\section{Microscopy analysis.}

Fungal development was examined in inoculated detached leaves. Leaves were first cleared in glacial acetic acid/absolute ethanol $(1: 1, \mathrm{vol} / \mathrm{vol})$ for 2 days at room temperature. They were then immersed in a lactophenol-trypan blue solution for a few seconds and were washed twice in deionized water before observations under a light microscope (Leica, Bensheim, Germany).

Accumulation of autofluorescent compounds in the inoculated leaves was followed by epifluorescence microscopy, using an inverted microscope (Leitz DM IRBE) with excitation filter BP 450 to $490 \mathrm{~nm}$ and barrier filter LP $520 \mathrm{~nm}$. Images were recorded with a color digital camera (Photonic Science, Robertsbridge, U.K.).

Production of $\mathrm{H}_{2} \mathrm{O}_{2}$ was detected in inoculated detached leaves using the DAB technique according to Lu and Higgins (1998). A solution containing $0.2 \%$ (wt/vol) of 3,3-diaminobenzidine tetrahydrochloride (Sigma) and $20 \mathrm{mM}$ $\mathrm{MnCl}_{2}, 4 \mathrm{H}_{2} \mathrm{O}$ was infiltrated under vacuum into the leaves. They were kept overnight at room temperature, were cleared in ethanol/chloroform $(3: 1, \mathrm{vol} / \mathrm{vol})$, and were observed under a light microscope.

\section{Construction of cDNA macroarrays containing defense-related genes.}

A selection of 126 Medicago truncatula EST corresponding to 92 TC sequences was performed using the TIGR database and the MENS database. The EST were selected according to their putative defense and signaling related functions, and the bacterial clones were picked from the "MtB INRA libraries" (Journet et al. 2002). Each plasmid was purified, the size of the inserts was checked by restriction digestion, and identity was confirmed by sequencing for $10 \%$ of the clones. The inserts were amplified by PCR, using T3 and T7 primers. Quality, size, and amount of PCR products were controlled on agarose gels. PCR product was quantified in each reaction by spectrophotometric measurement at $260 \mathrm{~nm}$. Concentration of the PCR fragments was adjusted to 0.2 to $0.5 \mu \mathrm{g} / \mu \mathrm{l}$ in $50 \%$ dimethyl sulfoxide (Sigma), and each sample was spotted in duplicate onto positively charged nylon membranes (Hybond $\mathrm{N}+$, Amersham Biosciences, Uppsala, Sweden) by a Eurogridder spotting robot (Plateforme de génomique fonctionnelle, Génopôle Toulouse). Several controls were evenly spotted on the array to be used for standardization and normalization purposes. A total of 20 empty spots on each membrane were included for measurements of local background intensity. Twelve spots containing a cDNA encoding the coat protein (CP) of the Plum pox virus (PPV), which does not crosshybridize with $M$. truncatula genomic DNA, were also included to be used as external controls (spikes). M. truncatula genomic DNA, which displays a constant signal intensity following hybridization, was printed eight times onto the array and was used as internal control for normalization.

\section{Macroarrays experiments.}

Three independent inoculation experiments were performed, and inoculated and noninoculated (control) leaves were collected at each timepoint. Total RNA was extracted using the Extract All reagent (Eurobio, Les Ulis, France) for each sample. Total RNA $(40 \mu \mathrm{g})$ was mixed with $2 \cdot 10^{-4} \mu \mathrm{g}$ of the PPV CP mRNA, which was transcribed in vitro from the pTP7 plasmid using the Riboprobe combination system kit (Promega, Madison, WI, U.S.A.). Reverse transcription was performed with the Superscript first strand synthesis system for RT-PCR (Invitrogen, Carlsbad, CA, U.S.A.) and $\left[\alpha^{-3} \mathrm{P}\right] \mathrm{dCTP}$, to generate radioactive probes. Macroarray prehybridization and hybridization were performed as described on the Génopôle Toulouse Midi-Pyrénées website. Membranes were washed two times in $0.5 \times \mathrm{SSC}(1 \times \mathrm{SSC}$ is $0.15 \mathrm{M} \mathrm{NaCl}$ plus $0.015 \mathrm{M}$ sodium citrate), $0.1 \% \mathrm{SDS}$ and once in $0.1 \times \mathrm{SSC}, 0.1 \% \mathrm{SDS}$, $15 \mathrm{~min}$ each at $65^{\circ} \mathrm{C}$ and then was exposed for $48 \mathrm{~h}$ to imaging plates of a PhosphorImager (Molecular Dynamics, Sunnyvale, CA, U.S.A.).

\section{Data acquisition and analysis.}

Data acquisition and quantification were performed with ImageQuant software (Molecular Dynamics). Grids were manually defined and adjusted to ensure optimal spot recognition. For each EST, raw values obtained for duplicate spots were compared. When the values of duplicates differed by more than $5 \%$, both data were discarded. Normalization procedures of the acquired data involved several steps: i) averaging of the duplicate signals; ii) subtraction of local background, calculated by the average of the values obtained for the four nearest empty spots on the filter; iii) normalization by the external (spike) and internal (genomic DNA signal) controls; iv) calculation of ratios with signals obtained from noninoculated control leaves at the same timepoint from the same experiment; $v$ ) averaging of independent replicates; and vi) averaging of all the ratios found with EST belonging to the same TC. Geneclustering analyses were realized using Cluster and Treeview programs (Eisen et al. 1998), using average linkage. Normalized ratios above 2 and below 0.5 were considered as significant for gene induction and repression, respectively.

\section{Northern blot analysis.}

Total RNAs $(15 \mu \mathrm{g})$ extracted as described above from inoculated or noninoculated Jemalong and F83005.5 leaves were run on a formaldehyde gel and were blotted onto a nylon 
membrane (Hybond $\mathrm{N}+$, Amersham Pharmacia Biotech). Blots were hybridized at $65^{\circ} \mathrm{C}$ by purified $\left[\alpha{ }^{32} \mathrm{P}\right] \mathrm{dCTP}$ or digoxigenin-labeled PCR fragments in Church buffer. Membranes were washed twice in $0.5 \times \mathrm{SSC}, 0.1 \% \mathrm{SDS}$ and in $0.1 \times \mathrm{SSC}$, $0.1 \%$ SDS for $15 \mathrm{~min}$ each at $65^{\circ} \mathrm{C}$. They were then exposed to imaging plates of a PhosphorImager, and Northern results were visualized with ImageQuant software.

\section{ACKNOWLEDGMENTS}

The authors thank R. O'Connell for critically reviewing the manuscript. We are also grateful to M. Ravelonandro and to M. B. Dickman who provided, respectively, the pTP7 plasmid and the $C$. trifolii race 1 . C. Torregrosa is supported by a grant from the French Ministère de l'Education Nationale, de la Recherche et de la Technologie. Financial support was provided by the ATS INRA project on M. truncatula (number P00241) and by the Toulouse-Génopôle program.

\section{LITERATURE CITED}

Bannerot, H. 1965. Résultats d'infection d'une collection de haricot par six races physiologiques d'anthracnose. Annu. Amélioration Plantes $15: 210-222$

Barker, D. G., Blanchi, S., Blondon, F., Detté, Y., Duc, G., Flament, P., Gallusci, P., Génier, P., Guy, P., Muel, X., Tourneur, J., Dénarié, J., and Huguet, T. 1990. Medicago truncatula, a model plant for studying the molecular genetics of the Rhizobium-legume symbiosis. Plant Mol. Biol. Rep. 8:40-49.

Boudart, G., Dechamp-Guillaume, G., Lafitte, C., Ricart, G., Barthe, J., Mazau, D., and Esquerré-Tugayé, M. T. 1995. Elicitors and suppressors of hydroxyproline-rich glycoprotein accumulation are solubilized from plant cell walls by endopolygalacturonase. Eur. J. Biochem. 232:449-457.

Brown, I., Mansfield, J., and Bonas, U. 1995. hrp genes in Xanthomonas campestris pv. vesicatoria determine ability to suppress papilla deposition in pepper mesophyll cells. Mol. Plant-Microbe Interact. 8:825-836.

Cook, D. R. 1999. Medicago truncatula-a model in the making! Curr. Opin. Plant Biol. 2:301-304.

Cook, D. R., and Dénarié, J. 2000. Progress in the genomics of Medicago truncatula and the promise of its application to grain legume crops. Grain Legumes 28:12-13.

Cordero, J. C., and Skinner, D. Z. 2002. Isolation from alfalfa of resistance gene analogues containing nucleotide binding sites. Theor. Appl. Genet. 104:1283-1289.

Croft, K., Juttner, F., and Slusarenko, A. J. 1993. Volatile products of the lipoxygenase pathway evolved from Phaseolus vulgaris (L.) leaves inoculated with Pseudomonas syringae pv. phaseolicola. Plant Physiol. 101:13-24.

Dixon, R. A., and Harrison, M. J. 1994. Early events in the activation of plant defense responses. Annu. Rev. Phytopathol. 32:479-501.

Dixon, R. A., Lamb, C. J., Masoud, S., Sewalt, V. J., and Paiva, N. L. 1996. Metabolic engineering: Prospects for crop improvement through the genetic manipulation of phenylpropanoid biosynthesis and defense responses-A review. Gene 179:61-71.

Dixon, R. A., Achnine, L., Kota, P., Liu, C.-J., Reddy, M. S. S., and Wang, L. 2002. The phenylpropanoid pathway and plant defence-a genomic perspective. Mol. Plant Pathol. 3:371-390.

Eisen, M. B., Spellman, P. T., Brown, P. O., and Botstein, D. 1998. Cluster analysis and display of genome-wide expression patterns. Proc. Natl. Acad. Sci. U.S.A. 95:14863-14868.

Elgin, J. H., and Ostazeski, S. A. 1982. Evaluation of selected alfalfa cultivars and related Medicago species for resistance to race 1 and 2 anthracnose. Crop Sci. 22:39-42.

Elgin, J. H., and Ostazeski, S. A. 1985. Inheritance of resistance to race 1 and race 2 anthracnose in Arc and Saranac AR alfalfa. Crop Sci. 25:861-865

Endre, G., Kereszt, A., Kevei, Z., Mihacea, S., Kalo, P., and Kiss, G. B. 2002. A receptor kinase gene regulating symbiotic nodule development. Nature 417:962-966.

Esquerré-Tugayé, M.-T., Mazau, D., Barthe, J.-P., Lafitte, C., and Touzé, A. 1992. Mechanisms of resistance to Colletotrichum species. Pages 121-133 in: Colletotrichum : Biology, Pathology and Control. J. A. Bailey and M. J. Jeger, eds. CAB International, Wallingford, U.K.

Esquerré-Tugayé, M.-T., Campargue, C., and Mazau, D. 1999. The response of plant cell wall hydroxyprolin-rich glycoproteins to microbial pathogens and their elicitors. Pages 157-170 in: Pathogenesis-Related Proteins in Plants. S. K. Datta and S. Muthukrishnan, eds. CRC Press, Boca Raton, FL, U.S.A.
Gamas, P., de Carvalho-Niebel, F., Lescure, N., and Cullimore, J. 1996. Use of a subtractive hybridization approach to identify new Medicago truncatula genes induced during root nodule development. Mol. PlantMicrobe Interact. 9:233-242.

Gamas, P., de Billy, F., and Truchet, G. 1998. Symbiosis-specific expression of two Medicago truncatula nodulin genes, MtN1 and MtN13, encoding products homologous to plant defense proteins. Mol. PlantMicrobe Interact. 11:393-403.

Geffroy, V., Sévignac, M., De Oliveira, J. C. F., Fouilloux, G., Skroch, P., Thoquet, P., Gepts, P., Langin, T., and Dron, M. 2000. Inheritance of partial resistance against Colletotrichum lindemuthianum in Phaseolus vulgaris and co-localization of quantitative trait loci with genes involved in specific resistance. Mol. Plant-Microbe Interact. 13:287-296.

Glazebrook, J. 2001. Genes controlling expression of defense responses in Arabidopsis-2001 status. Curr. Opin. Plant Biol. 4:301-308.

Glazebrook, J., Chen, W., Estes, B., Chang, H. S., Nawrath, C., Metraux, J. P., Zhu, T., and Katagiri, F. 2003. Topology of the network integrating salicylate and jasmonate signal transduction derived from global expression phenotyping. Plant J. 34:217-228.

Graham, P. H., and Vance, C. P. 2003. Legumes: Importance and constraints to greater use. Plant Physiol. 131:872-877.

Hammerschmidt, R. 1999. Phytoalexins: What have we learned after 60 years? Annu. Rev. Phytopathol. 37:285-306.

Handberg, K., and Stougaard, J. 1992. Lotus japonicus, an autogamous, diploid legume species for classical and molecular genetics. Plant J. 2:487-492.

Heath, M. C. 2000. Nonhost resistance and nonspecific plant defenses. Curr. Opin. Plant Biol. 3:315-319.

Journet, E.-P., van Tuinen, D., Gouzy, J., Crespeau, H., Carreau, V., Farmer, M.-J., Niebel, A., Schiex, T., Jaillon, O., Chatagnier, O., Godiard, L., Micheli, F., Kahn, D., Gianinazzi-Pearson, V., and Gamas, P. 2002. Exploring root symbiotic programs in the model legume Medicago truncatula using EST analysis. Nucleic Acids Res. 30:55795592.

Kawaguchi, M., Motomura, T., Imaizumi-Anraku, H., Akao, S., and Kawasaki, S. 2001. Providing the basis for genomics in Lotus japonicus: The accessions Miyakojima and Gifu are appropriate crossing partners for genetic analysis. Mol. Genet. Genomics 266:157-166.

Kunkel, B., and Brooks, D. 2002. Cross talk between signaling pathways in pathogen defense. Curr. Opin. Plant Biol. 5:325-331.

Lenné, J. M. 1992. Colletotrichum diseases of legumes. Pages 134-166 in: Colletotrichum: Biology, Pathology and Control. J. A. Bailey and M. J. Jeger, eds, CAB International, Wallingford, U.K.

Lu, H., and Higgins, V. J. 1998. Measurement of active oxygen species generated in planta in response to elicitor AVR9 of Cladosporium fulvum. Physiol. Mol. Plant Pathol. 52:35-51.

Madsen, E. B., Madsen, L. H., Radutoiu, S., Olbryt, M., Rakwalska, M., Szczyglowski, K., Sato, S., Kaneko, T., Tabata, S., Sandal, N., and Stougaard, J. 2003. A receptor kinase gene of the LysM type is involved in legume perception of rhizobial signals. Nature 425:637-640.

Mène-Saffrané, L., Esquerré-Tugayé, M. T., and Fournier, J. 2003. Constitutive expression of an inducible lipoxygenase in transgenic tobacco decreases susceptibility to Phytophthora parasitica var nicotianae. Mol. Breeding 12:271-282.

Mithöfer, A. 2002. Suppression of plant defence in rhizobia-legume symbiosis. Trends Plant Sci. 7:440-444.

Mould, M. J. R., Boland, G. J., and Robb, J. 1991a. Ultrastructure of the Colletotrichum trifolii-Medicago sativa pathosystem. I. Pre-penetration events. Physiol. Mol. Plant Pathol. 38:179-194.

Mould, M. J. R., Boland, G. J., and Robb, J. 1991b. Ultrastructure of the Colletotrichum trifolii-Medicago sativa pathosystem. II. Post-penetration events. Physiol. Mol. Plant Pathol. 38:195-210.

O'Neill, N. R., and Bauchan, G. R. 2000. Sources of resistance to anthracnose in the annual Medicago core collection. Plant Dis. 84:261-267.

Osbourn, A. E. 1996. Preformed antimicrobial compounds and plant defense against fungal attack. Plant Cell 8:1821-1831.

Parniske, M. 2000. Intracellular accommodation of microbes by plants: A common developmental program for symbiosis and disease? Curr. Opin. Plant Biol. 3:320-328.

Prospéri, J. M. 2000. The genus Medicago and the genetic resources of Medicago truncatula. Grain Legumes 28:14-15.

Rancé, I. I., Fournier, J., and Esquerré-Tugayé, M. T. 1998. The incompatible interaction between Phytophthora parasitica var. nicotianae race 0 and tobacco is suppressed in transgenic plants expressing antisense lipoxygenase sequences. Proc. Natl. Acad. Sci. U.S.A. 95:65554-65559

Ryan, C. A. 1990. Protease inhibitors in plants: Genes for improving defenses against insects and pathogens. Annu. Rev. Phytopathol. 28:425449.

Schenk, P., Kazan, K., Wilson, I., Anderson, J., Richmond, T., Somerville, S., and Manners, J. 2000. Coordinated plant defense responses in 
Arabidopsis revealed by microarrays analysis. Proc. Natl. Acad. Sci. U.S.A. Oct 10 97:11655-11660.

Sherriff, C., Whelan, M. J., Arnold, G. M., Lafay, J. F., Brygoo, Y., and Bailey, J. A. 1994. Ribosomal DNA sequence analysis reveals new species groupings in the genus Colletotrichum. Exp. Mycol. 18:121-138.

Sticher, L., Mauch-Mani, B., and Métraux, J. P. 1997. Systemic acquired resistance. Annu. Rev. Phytopathol. 35:235-270.

Stougaard, J. 2001. Genetics and genomics of root symbiosis. Curr. Opin. Plant Biol. 4:328-335.

Stracke, S., Kistner, C., Yoshida, S., Mulder, L., Sato, S., Kaneko, T., Tabata, S., Sandal, N., Stougaard, J., Szczyglowski, K., and Parniske, M. 2002. A plant receptor-like kinase required for both bacterial and fungal symbiosis. Nature 417:959-962.

Suzuki, H., Achnine, L., Xu, R., Matsuda, S., and Dixon, R. 2002. A genomics approach to the early stages of triterpene saponin biosynthesis in Medicago truncatula. Plant J. 32:1033-1048.

Szybiak-Strozycka, U., Lescure, N., Cullimore, J., and Gamas, P. 1995. A cDNA encoding a PR-1-like protein in the model legume Medicago truncatula. Plant Physiol. 107:273-274.

Tenhaken, R., Levine, A., Brisson, L. F., Dixon, R. A., and Lamb, C. 1995. Function of the oxidative burst in hypersensitive disease resistance. Proc. Natl. Acad. Sci. U.S.A. 92:4158-4163.

Thoquet, P., Ghérardi, M., Journet, E.-P., Kereszt, A., Ané, J.-M., Prospéri, J.-M., and Huguet, T. 2002. The molecular genetic linkage map of the model legume Medicago truncatula: An essential tool for comparative legume genomics and the isolation of agronomically important genes. BMC Plant Biol. 2:1-13.

Tullu, A., Buchwaldt, L., Warkentin, T., Taran, B., and Vandenberg, A. 2003. Genetics of resistance to anthracnose and identification of AFLP and RAPD markers linked to the resistance gene in PI 320937 germplasm of lentil (Lens culinaris Medikus). Theor. Appl. Genet. 106:426-434.

Turner, J. G., Ellis, C., and Devoto, A. 2002. The jasmonate signal pathway. Plant Cell 14:S153-164.

van Loon, L. C. 1999. Occurrence and properties of plant pathogenesisrelated proteins. Pages 1-19 in: Pathogenesis-Related Proteins in Plants. S. K. Datta and S. Muthukrishnan, eds. CRC Press, Boca Raton, FL. U.S.A.

van Wees, S. C., Chang, H. S., Zhu, T., and Glazebrook, J. 2003. Characterization of the early response of Arabidopsis to Alternaria brassicicola infection using expression profiling. Plant Physiol. 132:606-617.

VandenBosch, K. A., and Stacey, G. 2003. Summaries of legume genomic projects from around the globe. Community resources for crops and models. Plant Physiol. 131:840-865.

Wojtaszek, P. 1997. Oxidative burst: An early plant response to pathogen infection. Biochem J. 322:681-692.

Zhu, H., Kim, D. J., Baek, J. M., Choi, H. K., Ellis, L. C., Kuester, H., McCombie, W. R., Peng, H. M., and Cook, D. R. 2003. Syntenic relationships between Medicago truncatula and Arabidopsis reveal extensive divergence of genome organization. Plant Physiol. 131:1018-1026.

\section{AUTHOR-RECOMMENDED INTERNET RESOURCES}

The Génopôle Toulouse Midi-Pyrénées website: genopole.toulouse.inra.fr The Institute of Genomic Research (TIGR) Medicago gene index: www.tigr.org/tdb/tgi/mtgi

The Medicago EST Navigation System (MENS) database: medicago.toulouse.inra.fr/EST

Stanford University Cluster and Treeview programs: rana.lbl.gov/EisenSoftware.htm 